\title{
EXTRA-ARTICULAR RECONSTRUCTION ASSOCIATED WITH THE ANTERIOR CRUCIATE LIGAMENT IN BRAZIL
}

\author{
RECONSTRUÇÃO EXTRA-ARTICULAR ASSOCIADA AO \\ LIGAMENTO CRUZADO ANTERIOR NO BRASIL
}

\author{
Camilo Partezani Helito, $, 1,2$ Carlos do Amaral Junior, ${ }^{2}$ Danilo Bordini Camargo, ${ }^{3}$ Marcelo Batista Bonadio, ${ }^{1}$ Jose Ricardo Pecora, ${ }^{1}$ \\ MARCO KaWAMURA DEMANGE
}

1. Universidade de São Paulo, Faculdade de Medicina, Hospital das Clínicas, Instituto de Ortopedia e Traumatologia (IOT/FMUSP), Knee Surgery Division, São Paulo, Brazil.

2. Hospital Sírio Libanês, São Paulo, SP, Brazil.

3. Clínica NOTE, Sorocaba, SP, Brazil.

\section{ABSTRACT}

Objective: To assess the knowledge and technical preferences of Brazilian knee surgeons in relation to the treatment of Anterior Cruciate Ligament (ACL) injuries using intra-articular reconstruction in combination with extra-articular reconstruction. Methods: A questionnaire consisting of 16 questions about intra-articular $A C L$ reconstruction in combination with extra-articular procedures and about the Anterolateral Ligament (ALL) was applied at the $48^{\text {th }}$ Brazilian Congress of Orthopedics. Results: One hundred thirty-seven surgeons answered the questionnaire. Most surgeons perform 10-30 ACL reconstructions per year, with the transtibial technique appearing as the most common. Most surgeons find some percentage of residual pivot-shift after reconstructions, but the minority performs extra-articular procedures on a routine basis. The main indications for extra-articular reconstruction are revision and profuse pivot-shift cases. Most surgeons consider the ALL a true ligament, but $46.7 \%$ with less biomechanical importance and $32.3 \%$ with greater importance in knee stability. However, 91.4\% had a positive perception of the reconstruction of this structure. Conclusion: Although the preferred technique is still the transtibial procedure, combined anatomical reconstructions already make up more than $50 \%$ of cases. Extra-articular reconstructions associated with the ACL are still performed by the minority of Brazilian surgeons, but $91.4 \%$ of them report having had a positive perception with their reconstruction. Level of Evidence III, Descriptive Study.

Keywords: Anterior cruciate ligament. Anterolateral ligament. Knee joint. Joint instability.

\section{RESUMO}

Objetivo: Avaliar o conhecimento e as preferências técnicas entre os cirurgiões de joelho brasileiros no tratamento das lesões do ligamento cruzado anterior, com reconstrução intra-articular associada à reconstrução extra-articular. Métodos: Foi aplicado questionário de 16 perguntas no $48^{\circ}$ Congresso Brasileiro de Ortopedia acerca de reconstrução intra-articular do ligamento cruzado anterior associada a procedimentos extra-articulares e sobre o ligamento anterolateral. Resultados: Responderam o questionário 137 cirurgiões. A maioria faz entre 10 e 30 reconstruções de ligamento cruzado anterior por ano, sendo a técnica transtibial a mais realizada. A maioria encontrou alguma porcentagem de pivot-shift residual após as reconstruções, mas a minoria realizou procedimento extra-articular de rotina. As indicações principais de reconstrução extra-articular foram casos de revisão e pivot-shift exuberante. A maioria considera o ligamento anterolateral um ligamento verdadeiro, porém 46,7\% o caraterizou com importância biomecânica menor e 32,3\% com importância maior na estabilidade do joelho, mas 91,4\% tiveram percepção positiva em relação à reconstrução dessa estrutura. Conclusão: Apesar da técnica de preferência ainda ser a transtibial, as reconstruções anatômicas combinadas já são mais de 50\% dos casos. As reconstruções extra-articulares associadas ao ligamento cruzado anterior ainda são feitas pela minoria dos cirurgiões brasileiros, mas 91,4\% deles referem ter tido uma percepção positiva com sua reconstrução. Nível de Evidência III, Estudo Descritivo.

Descritores: Ligamento cruzado anterior. Ligamento anterolateral. Articulação do joelho. Instabilidade articular.

Citation: Helito CP, Amaral Jr C, Camargo DB, Bonadio MB, Pecora JR, Demange MK. Extra-articular reconstruction associated with the anterior cruciate ligament in Brazil. Acta Ortop Bras. [online]. 2019;27(4):202-6. Available from URL: http://www.scielo.br/aob.

\section{INTRODUCTION}

Anterior cruciate ligament (ACL) injuries are one of the most common knee injuries. ${ }^{1}$ In the USA, for example, more than 200,000 ACL reconstructions are performed on average each year. ${ }^{2}$ Techniques for treating anterior knee instability have made considerable progress over the past 30 years, going from open to arthroscopic procedures, and from non-anatomical to more anatomical procedures. ${ }^{3}$

Even with the advances in techniques, many surgeons have noted that a not inconsiderable group of patients continue to have residual

All authors declare no potential conflict of interest related to this article.

Work conducted at the Musculoskeletal Medical Research Laboratory (LIM41), Department of Orthopedics and Traumatology of (FMUSP), São Paulo, SP, Brazil. Correspondence: Camilo Partezani Helito. Rua Dr. Ovídio Pires de Campos, 333, Cerqueira Cesar, São Paulo, SP, Brazil. 05403-010. camilo_helito@yahoo.com.br 
knee instability, even after technically adequate surgery. ${ }^{4,5}$ This instability can be measured objectively using the pivot-shift test, which ranges from minimal perceptible instability to an exacerbated degree, depending on the series used. ${ }^{6}$ The positivity of the pivot-shift test in the postoperative period is correlated with worse functionality of these patients. ${ }^{28}$

Due to this residual instability, the focus has shifted back to the extra-articular area of the knee, particularly as of 2013, because of studies related to the Anterolateral Ligament, and procedures performed as monotherapy in the past are now being used in combination with intra-articular ACL reconstruction. ${ }^{7-9}$

Due to the high frequency of $A C L$ injuries in sports, their social and economic impact, the considerable divergence between treatment types, and the importance of Brazilian literature, especially in articles related to the ALL and extra-articular reconstructions published in the last 5 years, it is pertinent to evaluate the perspectives and predilections of Brazilian surgeons in relation to this topic. ${ }^{10-13}$

Therefore, the aim of this study was to evaluate ACL reconstruction preferences among knee surgeons in Brazil, and to observe their knowledge and predilections with regards to extra-articular reconstructions and the Anterolateral Ligament.

\section{MATERIAL AND METHODS}

This is a descriptive study with the application of a questionnaire for Brazilian knee surgeons. The questionnaire was developed by the authors of this study (Appendix 1). The questionnaire, which consists of 16 questions, was applied to 137 orthopedists who perform knee surgery at the $48^{\text {th }}$ Brazilian Congress of Orthopedics. The questionnaire was answered voluntarily without the signing of an Informed Consent Form.

The questions were related to the number of $A C L$ reconstructions per year, type of technique most commonly used, clinical observations such as percentage of residual pivot-shift, percentage of association of extra-articular techniques (including ALL reconstruction) with intra-articular ACL technique, level of knowledge of ALL related studies, incidence of ALL reconstruction and criteria for indication, graft types for both $A C L$ and ALL reconstructions, and potential complications. The objective was to gain a better insight into the preferences and degree of knowledge of new extra-articular techniques, and to enable an understanding of the predilections and perceptions of the knee surgeons. We conducted a descriptive statistical analysis of the answers obtained, based on the questionnaire, in order to characterize the sample.

This research project was approved by the Scientific Committee of the Department of Orthopedics and Traumatology of the School of Medicine of Universidade de São Paulo at a meeting, under Research Protocol IOT No. 1321.

\section{RESULTS}

The origin and age of the patients are shown in Tables 1 and 2. Of the 137 participants, $28.5 \%$ answered that they perform fewer than 10 ACL reconstructions per year; 29.1\% perform between 10 and 30; $27.8 \%$ between 30 and 50; 12.4\% between 50 and 100, and only 2.2\% perform more than $100 \mathrm{ACL}$ reconstructions per year (Table 1). The ACL reconstruction technique preferred by $40.9 \%$ of knee surgeons was the Single-Bundle Transtibial Technique; followed by the Single-Bundle Transportal Technique preferred by $32.1 \%$ of the participants; $18.3 \%$ prefer Single-Bundle Outside In Reconstruction; 7.3\% prefer Double-Bundle Reconstruction, and the remaining $1.4 \%$ said they still perform Open ACL Reconstruction (Table 2). The incidence of residual instability determined by the pivot-shift test is described in Table 3.
Table 1. Number of Anterior Cruciate Ligament reconstructions performed per year by Brazilian surgeons who answered the questionnaire at the $48^{\text {th }}$ Brazilian Congress of Orthopedics.

\begin{tabular}{c|c|c}
\hline Number of Reconstructions/year & Number of surgeons & $\%$ \\
\hline$<10$ & 39 & 28.5 \\
\hline Between 10 and 30 & 40 & 29.1 \\
\hline Between 30 and 50 & 38 & 27.8 \\
\hline Between 50 and 100 & 17 & 12.4 \\
\hline$>100$ & 3 & 2.2 \\
\hline
\end{tabular}

Table 2. Preferred technique for Anterior Cruciate Ligament reconstructions of Brazilian surgeons who answered the questionnaire at the $48^{\text {th }}$ Brazilian Congress of Orthopedics.

\begin{tabular}{c|c|c}
\hline Preferred Technique for ACL reconstruction & No. of surgeons & $\%$ \\
\hline Open & 2 & 1,4 \\
\hline Arthroscopic Single-Bundle Transtibial & 56 & 40,9 \\
\hline Arthroscopic Single-Bundle Transportal & 44 & 32.1 \\
\hline Arthroscopic Single-Bundle Outside In & 25 & 18.3 \\
\hline Double-Bundle Arthroscopic & 10 & 7.3 \\
\hline
\end{tabular}

$\mathrm{ACL}-$ Anterior Cruciate Ligament.

\begin{tabular}{|c|c|c|}
\hline $\begin{array}{l}\text { Incidence of Residual Pivot-Shift } \\
\text { following ACL Reconstruction }\end{array}$ & No. of Surgeons & $\%$ \\
\hline Less than $5 \%$ & 2 & 1.4 \\
\hline Between 5 and $10 \%$ & 56 & 40.9 \\
\hline Between 10 and $15 \%$ & 44 & 32.1 \\
\hline Between 15 and $20 \%$ & 25 & 18.3 \\
\hline More than $20 \%$ & 10 & 7.3 \\
\hline
\end{tabular}

Regarding the combination of extra-articular reconstructions associated with ACL reconstruction, the majority of surgeons (73.7\%) answered that they did not use this procedure in reconstructions. Among those who do, $21.2 \%$ only perform the procedure in selected cases; $1.4 \%$ use it routinely in revision cases, and 3.6\% use the procedure routinely in primary and revision cases.

In an objective question about whether all the respondents were familiar with the ALL and its recent anatomical importance as well as surgical techniques for extra-articular reconstruction, $60.5 \%$ of respondents said they had only recently heard about the ALL; $32.1 \%$ said they had known about it for years, and $7.2 \%$ said they were not yet aware of the ligament.

Another question put to the surgeons concerned their opinion about the importance of the Anterolateral Knee Ligament. In the studied sample, $46.7 \%$ agree with the anatomical existence of the ligament, but believe it has little importance in the control of rotatory knee instability; only 32.3\% consider the ALL important as an anatomical and functional structure in the control of rotatory instability; $9.4 \%$ regard the ALL as a lateral structure, but not a ligament, and $6.5 \%$ regard the $A L L$ as a ligament, but without a functional role. $82.2 \%$ answered that they had not yet performed any ACL reconstruction in combination with ALL, and $17.8 \%$ had already performed the procedure at least once. Regarding the graft that would be chosen to perform Extra-articular ALL Reconstruction, $71.6 \%$ answered that they would use the Gracilis Tendon; $27.0 \%$ that they would use the lliotibial Tract or Band, and 1.4\% that they would only use Tissue Bank Tendons.

As concerns the fixation options for a potential ALL reconstruction, $55.5 \%$ said they use or would use Interference Screws; $33.5 \%$ said they prefer or would prefer to use Anchors; $5.8 \%$ would fix 
the ligament using only soft tissue and transosseous sutures, and $5.2 \%$ would use Biotenodesis Screws or Anchors.

Regarding the surgical indications for ALL reconstruction, the question was open to more than one answer for the interviewees, so that $75.1 \%$ consider a high-grade pivot-shift test the main indication. The other responses are described in Table 4.

Regarding the fixation of the ALL graft, the surgeons were asked at which angle of flexion or extension they would fix this graft. $45.2 \%$ would fix it at $30^{\circ}$ of flexion; $27.8 \%$ at $45^{\circ}$ of flexion; $19.7 \%$ would fix the graft in extension and $4.3 \%$ would fix it at $60^{\circ}$ of flexion. Regarding the use of a brace in extension in the postoperative period, $75.6 \%$ would not use it while $24.4 \%$ said they would. The complications found are described in Table 5. Participants could answer none, only one, or more than one complication.

Finishing with a subjective question, $91.4 \%$ answered that they had a positive perception after performing ALL reconstruction, while $8.6 \%$ answered that on the contrary, they would give the procedure a negative feedback.

\begin{tabular}{l} 
Table 4. Possible indications of Anterolateral Ligament reconstruction in \\
combination with Anterior Cruciate Ligament reconstruction by Brazilian \\
surgeons who answered the questionnaire at the 48th Brazilian Congress \\
of Orthopedics. \\
\hline \begin{tabular}{c|c}
\hline Indications for all reconstruction & $\%$ \\
\hline Acl revision & 63.5 \\
\hline High-grade pivot-shift & 75.1 \\
\hline Sports with rotation movements & 38.6 \\
\hline Ligament hypermobility & 5.1 \\
\hline Age <18 years & 3.6 \\
\hline Professional athletes & 5.8 \\
\hline Chronic acl injuries & 24.0 \\
\hline Lateral femoral notch & 11.6 \\
\hline Segond fracture & 36.4 \\
\hline
\end{tabular}
\end{tabular}

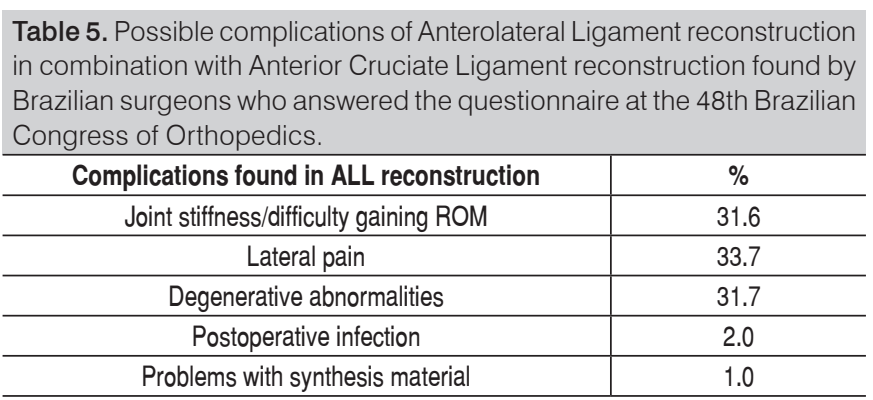

\section{DISCUSSION}

The main finding of this study is that there is still no consensus as to whether there is a need for extra-articular reconstruction combined with intra-articular reconstruction of the $\mathrm{ACL}$, or on the best technique for this potential reconstruction among Brazilian knee surgeons. This controversy is also present in international literature, with groups advocating opposing viewpoints on the ALL. ${ }^{14-17}$ Nevertheless, recent studies have shown a tendency to support the use of combined extra-articular reconstruction in selected cases. ${ }^{18,19}$

As regards the population that answered the questionnaire, the vast majority is in southeast Brazil, where most of the services accredited by the Brazilian Society of Knee Surgery are also located. Only about $1 / 6$ of the sample performs more than $50 \mathrm{ACL}$ reconstructions per year, a number similar to that found by Arliani et al. ${ }^{20}$ in a study published 5 years ago, showing that few surgeons in Brazil handle a large volume of ACL reconstructions.

The transtibial isometric technique continues to be the preferred technique of most Brazilian surgeons on an individual basis, although so-called anatomical reconstructions, if analyzed in a combined manner, together with transportal and outside in reconstructions, amount to more than $50 \%$ of cases. These data show the tendency towards a change of technique in Brazil, as is the case at other international centers, albeit more slowly.

Regarding residual instability measured by the pivot-shift test, only $19.7 \%$ reported having observed this phenomenon in a few patients, which shows that it is a fairly common situation in the postoperative period. The presence of residual pivot-shift denotes some degree of rotatory instability and is related to poorer post-ACL reconstruction functional outcomes. ${ }^{21}$ One of the advantages of extra-articular reconstruction is that it eliminates this instability. Clinical studies have already shown that the use of combined extra-articular reconstruction is able to reduce pivot-shift and the retear rate. ${ }^{18,22}$ Rezende et al. ${ }^{10}$ showed, in a systematic review, that the addition of extra-articular reconstruction improves both pivot-shift and anteroposterior instability in patients. Along the same lines, Ibrahim et al. ${ }^{23}$ showed lower KT-1000 in patients who had undergone combined reconstruction.

In the questions specifically focusing on extra-articular reconstructions, the vast majority of surgeons do not perform the procedure, while those who do only perform a very limited number of procedures. Only about $5 \%$ use this practice routinely, either in primary or revision reconstructions, and only $17.8 \%$ have performed ALL reconstruction at least once. Although countries such as Italy and France use lateral reinforcement routinely, American surgeons stopped using this technique in the late 1980s, which influenced much of the world. Specifically with regards to the ALL, most surgeons appeared to have heard of this structure only recently, which is acceptable since anatomical studies focused on this structure began in 2012 with Vincent et al., ${ }^{24}$ and increased significantly in 2013 after the studies by Claes et al. ${ }^{7}$ and Helito et al. ${ }^{9}$ Only a third of interviewees, however, believe that the ALL is of significant relevance in rotatory stability of the knee. Biomechanical studies have presented considerable controversy regarding its role, without a clear consensus in the literature to date, although with a tendency to consider the ALL significant after the latest studies by Rasmussen et al., ${ }^{25}$ Nitri et al. ${ }^{26}$ and Sonnery-Cottet et al. ${ }^{18}$

Regarding fixation techniques, most surgeons opted for the use of the gracilis tendon as a graft and fixation with interference screws in primary reconstructions, which is also the preferred technique of Sonnery-Cottet et al. ${ }^{18}$ in the most extensive series published to date on ALL reconstruction and of the author of this article. Nevertheless, the iliotibial tract graft may be used in revision cases, especially in combination with $\mathrm{ACL}$ reconstruction using patellar tendon.

The indications for reconstructions presented are also consistent with the current literature. ${ }^{16}$ Cases of reconstruction revision and patients with grosser instability based on the pivot-shift test were the most frequent indications found. Limited consensus was also achieved with respect to the fixation angle, with the majority choosing to fix at 30 and 45 degrees of flexion. Although biomechanical studies have shown that the fixation of a Lemaire tenodesis can be performed between 0 and 60 degrees without alterations in knee biomechanics, Inderhaug et al. ${ }^{27}$ showed that ALL reconstructions should be fixed in extension.

Despite the lack of consensus among Brazilian surgeons on the vast majority of questions presented, this is also a worldwide trend in this field, with some lines of research advocating extra-articular reconstruction and others supporting only isolated intra-articular reconstruction. Knowing national trends is important to understand where we can focus our lines of research and how to guide our patients. 


\section{CONCLUSION}

Although the preferred technique of the highest number of Brazilian knee surgeons $(40.9 \%)$ is still the transtibial procedure, so-called combined anatomical reconstructions already represent more than $50 \%$ of cases. Combined intra- and extra-articular ACL reconstruction is still performed by the minority of Brazilian surgeons, but $91.4 \%$ of these report having had a positive perception with ALL reconstruction.

AUTHORS' CONTRIBUTIONS: Each author made significant individual contributions to this manuscript. CPH (0000-0003-1139-2524)*: writing of the article and its review; CAJ (0000-0003-3270-6887)*: data analysis and writing of the articles; DBC (0000-0002-7848-4127)*: data analysis and writing of the articles and review of the article; MBB (0000-0002-4468-9693)*: statistical analysis and review of the article; JRP $(0000-0003-0287-4548)^{*}$ : review of the article and of the entire intellectual concept of the article; MKD (0000-0003-1999-9478)*: review of the article and of the entire intellectual concept of the article. *ORCID (Open Researcher and Contributor ID).

\section{REFERENCES}

1. Bradley JP, Klimkiewicz JJ, Rytel MJ, Powell JW. Anterior cruciate ligament injuries in the National Football League: epidemiology and current treatment trends among team physicians. Arthroscopy. 2002;18(5):502-9.

2. Leroux T, Wasserstein D, Dwyer T, Ogilvie-Harris DJ, Marks PH, Bach BR Jr, et al. The epidemiology of revision anterior cruciate ligament reconstruction in Ontario, Canada. Am J Sports Med. 2014;42(11):2666-72.

3. Chambat P, Guier C, Sonnery-Cottet B, Fayard JM, Thaunat M. The evolution of ACL reconstruction over the last fifty years. Int Orthop. 2013;37(2):181-6.

4. Hussein M, van Eck CF, Cretnik A, Dinevski D, Fu FH. Prospective randomized clinical evaluation of conventional single-bundle, anatomic single-bundle, and anatomic double-bundle anterior cruciate ligament reconstruction: 281 cases with 3- to 5-year follow-up. Am J Sports Med. 2012;40(3):512-20.

5. Vadalà AP, lorio R, De Carli A, Bonifazi A, lorio C, Gatti A, et al. An extra-articular procedure improves the clinical outcome in anterior cruciate ligament reconstruction with hamstrings in female athletes. Int Orthop. 2013;37(2):187-92.

6. Tanaka M, Vyas D, Moloney G, Bedi A, Pearle AD, Musahl V. What does it take to have a high-grade pivot shift? Knee Surg Sports Traumatol Arthrosc. 2012;20(4):737-42

7. Claes S, Vereecke E, Maes M, Victor J, Verdonk P, Bellemans J. Anatomy of the anterolateral ligament of the knee. J Anat. 2013;223(4):321-8.

8. Helito CP, Bonadio MB, Tirico LE, Gobbi RG, Demange MK, Angelini FJ, et al. Estudo anatômico do ligamento anterolateral do joelho. Rev Bras Ortop. 2013;48(4):368-73

9. Helito CP, Demange MK, Bonadio MB, Tírico LE, Gobbi RG, Pécora JR, et al. Anatomy and histology of the knee anterolateral ligament. Orthop J Sports Med. 2013;1(7):2325967113513546.

10. Rezende FC, de Moraes VY, Martimbianco AL, Luzo MV, de Silveira Franciozi CE, Belloti JC. Does Combined Intra- and Extraarticular ACL Reconstruction Improve Function and Stability? A Meta-analysis. Clin Orthop Relat Res. 2015;473(8):2609-18.

11. Vieira EL, Vieira EA, da Silva RT, Berlfein PA, Abdalla RJ, Cohen M. An anatomic study of the iliotibial tract. Arthroscopy. 2007;23(3):269-74.

12. Helito CP, Bonadio MB, Gobbi RG, da Mota EARF, Pécora JR, Camanho GL, et al. Is it safe to reconstruct the knee anterolateral ligament with a femoral tunnel? Frequency of lateral collateral ligament and popliteus tendon injury. Int Orthop. 2016;40(4):821-5.

13. Helito CP, Helito PV, Leão RV, Demange MK, Bordalo-Rodrigues M. Anterolateral ligament abnormalities are associated with peripheral ligament and osseous injuries in acute ruptures of the anterior cruciate ligament. Knee Surg Sports Traumatol Arthrosc. 2017;25(4):1140-8.

14. Dombrowski ME, Costello JM, Ohashi B, Murawski CD, Rothrauff BB, Arilla FV, et al. Macroscopic anatomical, histological and magnetic resonance imaging correlation of the lateral capsule of the knee. Knee Surg Sports Traumatol Arthrosc. 2016;24(9):2854-60.

15. Rahnemai-Azar AA, Miller RM, Guenther D, Fu FH, Lesniak BP, MusahI V, et al. Structural properties of the anterolateral capsule and iliotibial band of the knee. Am J Sports Med. 2016;44(4):892-7.
16. Sonnery-Cottet B, Daggett M, Fayard JM, Ferretti A, Helito CP, Lind M, et al. Anterolateral ligament expert group consensus paper on the management of internal rotation and instability of the anterior cruciate ligament: deficient knee. J Orthop Traumatol. 2017;18(2):91-106.

17. Sonnery-Cottet B, Saithna A, Helito C, Daggett M, Thaunat M. Regarding "anterolateral ligament of the knee, fact or fiction?". Arthroscopy. 2016;32(9):1740-1.

18. Sonnery-Cottet B, Saithna A, Cavalier M, Kajetanek C, Temponi EF, Daggett M5, et al. Anterolateral Ligament Reconstruction Is associated with significantly reduced $A C L$ graft rupture rates at a minimum follow-up of 2 Years. Am J Sports Med. 2017;45(7):1547-57.

19. Sonnery-Cottet B, Thaunat M, Freychet B, Pupim BH, Murphy CG, Claes S Outcome of a combined anterior cruciate ligament and anterolateral ligament reconstruction technique with a minimum 2-year follow-up. Am J Sports Med. 2015;43(7):1598-605.

20. Arliani GG, Astru DC, Kanas M, Kaleka CC, Cohen M. Anterior cruciate ligament injury: treatment and rehabilitation. Current perspectives and trends. Rev Bras Ortop. 2015;47(2):191-6.

21. Sakai H, Hiraoka H, Yashiki M. Gravity-assisted pivot-shift test can predict the function of the reconstructed anterior cruciate ligament. Knee Surg Sports Traumatol Arthrosc. 2011;19(4):572-8

22. Trojani $C$, Beaufils $P$, Burdin G, Bussière $C$, Chassaing V, Dijan $P$, et al. Revision ACL reconstruction: influence of a lateral tenodesis. Knee Surg Sports Traumatol Arthrosc. 2012;20(8):1565-70.

23. Ibrahim SA, Shohdy EM, Marwan Y, Ramadan SA, Almisfer AK, Mohammad $\mathrm{MW}$, et al. Anatomic reconstruction of the anterior cruciate ligament of the knee with or without reconstruction of the anterolateral ligament. Am J Sports Med. 2017;45(7):1558-66

24. Vincent JP, Magnussen RA, Gezmez F, Uguen A, Jacobi M, Weppe F, et al. The anterolateral ligament of the human knee: an anatomic and histologic study. Knee Surg Sports Traumatol Arthrosc. 2012;20(1):147-52.

25. Rasmussen MT, Nitri M, Williams BT, Moulton SG, Cruz RS, Dornan GJ, et al. An in vitro robotic assessment of the anterolateral ligament, part 1: secondary role of the anterolateral ligament in the setting of an anterior cruciate ligament injury. Am J Sports Med. 2016;44(3):585-92.

26. Nitri M, Rasmussen MT, Williams BT, Moulton SG, Cruz RS, Dornan GJ, et al An in vitro robotic assessment of the anterolateral ligament, part 2: anterolateral ligament reconstruction combined with anterior cruciate ligament reconstruction. Am J Sports Med. 2016;44(3):593-601.

27. Inderhaug E, Stephen JM, Williams A, Amis AA. Biomechanical comparison of anterolateral procedures combined with anterior cruciate ligament reconstruction. Am J Sports Med. 2017;45(2):347-54.

28. Ayeni OR, Chahal M, Tran MN, Sprague S. Pivot shift as an outcome measure for ACL reconstruction: a systematic review. Knee Surg Sports Traumatol Arthrosc. 2012;20(4):767-77. 


\begin{tabular}{|c|c|}
\hline \multicolumn{2}{|c|}{ Anterolateral Ligament $-48^{\text {th }}$ СВОТ congress } \\
\hline 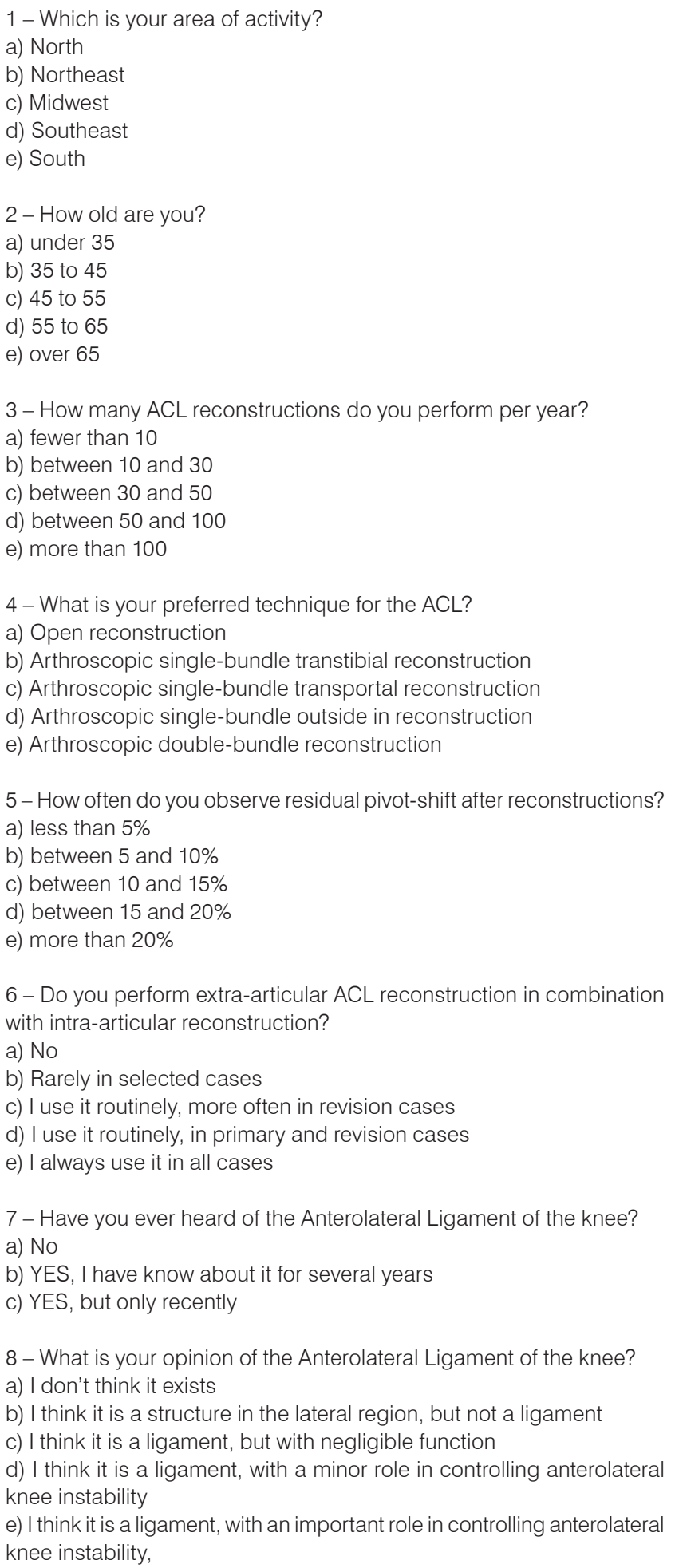 & $\begin{array}{l}12 \text { - Which would be your indications for Anterolateral Ligament recon- } \\
\text { struction (mark all those you consider pertinent) } \\
\text { a) reconstruction revision } \\
\text { b) high-degree pivot-shift upon physical examination } \\
\text { c) sports that involve knee rotation/pivoting movements } \\
\text { d) Ligament hypermobility } \\
\text { e) Age under } 18 \text { years } \\
\text { f) Professional athletes } \\
\text { g) Chronic ACL injuries } \\
\text { h) Lateral femoral notch sign ("Hill-Sachs lesion of the knee") } \\
\text { i) Segond fracture } \\
\text { 13-At how many degrees of knee flexion would you perform the fixation } \\
\text { of the anterolateral ligament graft? } \\
\text { a) full extension } \\
\text { b) } 30 \text { degrees of flexion } \\
\text { c) } 45 \text { degrees of flexion } \\
\text { d) } 60 \text { degrees of flexion } \\
\text { e) } 90 \text { degrees of flexion }\end{array}$ \\
\hline
\end{tabular}

